\title{
MANAJEMEN BOARDING SCHOOL DALAM UPAYA MENINGKATKAN KUALITAS PEMBELAJARAN DI SMP NURUL HAYAJ KETANGGUNGAN BREBES
}

\author{
Muhammad Izzudin \\ IAIN Syekh Nurjati Cirebon \\ zudinndut9@gmail.com \\ Dedi Djubaedi \\ IAIN Syekh Nurjati Cirebon \\ djubaedi.dedi@yahoo.co.id \\ Huriyah \\ IAIN Syekh Nurjati Cirebon \\ 61huriyah@gmail.com
}

\begin{abstract}
The objectives of this research are: 1) To understand the implementation of Boarding School Management at Nurul Hayah Middle School. 2) To understand the efforts of Boarding School Management at Nurul Hayah Middle School to improve the quality of learning. 3) To understand the constraints of implementing Boarding School Management in an effort improve the quality of learning. The method used in this research is qualitative method. Collecting data in this study, namely: 1) Observation, 2) Interview, 3) Documentation. The data analysis techniques are: a) Data Reduction, b) Data Presentation (Data (Display), c). Verification. The conclusions of this study are: 1) The boarding school management pattern at SMP Nurul Hayah is an integrated management pattern between the boarding school and the school. Dormitory management has the aim of internalizing religious values in students as early as possible, educating akhlakul karimah, having Islamic scientific knowledge and cultivating talents, potentials and skills as a provision for student life in the future. 2) Boarding school management at Nurul Hayah Middle School in detail are as follows: a) Planner for Boarding Schools, b) Organizing Boarding Schools, 3) Movement and Implementation of Boarding Schools
\end{abstract}

Keywords : Boarding School Management, Improving Learning Quality

\begin{abstract}
Abstrak
Tujuan penelitian ini adalah: 1) Untuk memahami penerapan Manajemen Boarding School di SMP Nurul Hayah.2) Untuk memahami upaya- upaya Manajemen Boarding School di SMP Nurul Hayah dalam meningkatkan kualitas pembelajaran.3) Untuk memahami kendalkendala penerapan Manajemen Boarding School dalam upaya meningkatkan kulitas pembelajaran. Metode yang digunakan dalam penelitian ini adalah metode kualitatif. Pengumpulan data dalam penelitian ini yaitu : 1) Observasi, 2) Wawancara, 3) Dokumentasi. Adapun teknik analisis data yaitu : a) Reduksi Data, b) Penyajian Data (Data (Display), c). Verifikasi. Kesimpulan dari penelitian ini yaitu: 1)Pola manajemen boarding school di SMP Nurul Hayah adalah pola manajemen terintegrasi antara boarding school
\end{abstract}


dengan Sekolah. Manajemen asrama memiliki tujuan internalisasi nilai-nilai keagamaan dalam diri siswa sedini mungkin, pendidikan akhlakul karimah, memiliki khasanah keilmuan Islam serta menumbuhkan bakat, potensi, dan skill sebagai bekal hidup siswa di masa yang akan datang.2) Manajemen boarding school di SMP Nurul Hayah secara rinci adalah sebagai berikut : a) Perencanaa Boarding School, b) Pengorganisasian Boarding School, 3) Penggerakan dan Pelaksanaan Boarding School

\section{Kata Kunci: Manajemen Boarding School, Meningkatkan Kualitas Pembelajaran.}

\section{PENDAHULUAN}

Globalisasi merupakan aspek yang meniscayakan terjadinya perubahan di segala aspek kehidupan, termasuk perubahan orientasi, persepsi dan tingkat selektifitas masyarakat Indonesia terhadap pendidikan. Padahal pendidikan, mempunyai tugas menyiapkan sumber daya manusia untuk pembangunan serta suatu sistem yang memiliki kegiatan yang cukup kompleks, meliputi berbagai komponen yang berkaitan satu sama lain (Ali Murtado: 2012) Secara tersirah bahwa tujuan pendidikan ditujukan untuk meningkatkan kualitas manusia, yaitu manusia yang beriman dan bertakwa kepada Tuhan Yang Maha Esa, berbudi pekerti luhur, berkepribadian, mandiri, maju, cerdas, kreatif, terampil, disiplin serta memilik etos kerja, bertanggungjawab.

Ada jargon-jargon yang menyatakan bahwa "Siapa yang dapat mengerjakan sesuatu secara cepat dan tepat, maka dia akan menguasai keadaan". Itulah potret keadaan/ situasi, dimana orang biasa menyebutnya dengan terma globalisasi. Kehidupan dunia pendidikan yang penuh dengan persaingan Termasuk pendidikan Islam di dalamnya merupakan warisan peradaban Islam, sekaligus asset bagi pembangunan pendidikan nasional seringkali berhadapan dengan berbagai problematika yang tidak ringan. Sehingga, mutu pendidikan Islam sendiri juga seringkali menunjukkan keadaan yang kurang menggembirakan.Eksistensi lembaga pendidikan Islam di Indonesia sendiri telah mengalami berbagai perkembangan ujuannya diadakan penelitian ini untuk mengetahui adakah hubungan antara budaya organisasi dengan turnover intention guru SMK Ponpes Manba'ul 'Ulum Cirebon, dan untuk mengetahui adakah hubungan antara gaya kepemimpinan kepala sekolah dengan turnover intention guru SMK Ponpes Manba'ul 'Ulum Cirebon, serta untuk mengetahui adakah pengaruh secara simultan antara budaya organisasi dan gaya kepemimpinan kepala sekolah dengan turnover intention guru SMK Ponpes Manba'ul 'Ulum Cirebon.

\section{METODE}

Penelitian dengan judul "manajemen Boarding School Dalam Upaya Meningkatkan Kualitas Pembelajaran Di Smp Nurul Hayah Ketanggungan Brebes" merupakan penelitian dengan pendekatan kualitatif. Pendekatan kualitatif. Penerapan pendekatan kualitatif dengan pertimbangan kemungkinan data yang diperoleh di lapangan berupa data dalam bentuk fakta yang perlu adanya analisis secara mendalam. Maka pendekatan kualitatif akan lebih mendorong pada pencapaian data yang bersifat lebih mendalam terutama dengan keterlibatan peneliti sendiri di lapangan.

Penerapan pendekatan kualitatif dengan pertimbangan kemungkinan data yang diperoleh di lapangan berupa data dalam bentuk fakta yang perlu adanya analisis secara mendalam. Maka pendekatan kualitatif akan lebih mendorong pada pencapaian data yang bersifat lebih mendalam terutama dengan keterlibatan peneliti sendiri di lapangan. Dalam penelitian kualitatif, peneliti menjadi instrument utama dalam mengumpulkan data yang dapat berhubungan langsung dengan instrument atau objek penelitian..

Secara umum ciri-ciri penelitian yang menggunakan pendekatan kualitatif diantaranya sebagai berikut (Suharsini:2006129):

a. Tatanan alamiah merupakan sumber data yang bersifat langsung. Penelitian kualitatif melakukan penelitian pada latar alamiah. Sebuah fenomena pada dasarnya merupakan keutuhan yang tidak dapat dipahami jika dipisahkan dari konsteknya. Oleh karena itu memahami fenomena secara langsung dan mendalam menjadi kunci pokok pendekatan kualitatif. 
b. Manusia sebagai alat instrumen. Dalam penelitian kualitatif peneliti sebagai pengumpul data yang utama. Melalui pengamatan berperan serta peneliti menjadi bagian dari fokus masalah yang diteliti.

c. Sampel bersifat deskriptif. Penelitian kualitatif mendeskripsikan makna data atau fenomena yang ditangkap oleh peneliti dengan menggunakan bukti-buktinya. Pemaknaan terhadap fenomena tersebut banyak bergantung pada kemampuan dan ketajaman peneliti dalam menganalisisnya. Dalam melakukan analisis peneliti mengajukan beberapa pertanyaan yang bersifat radikal sehingga dengan pemaknaan terhadap suatu gejala deskripsi yang dibuatnya bersifat luas dan tajam.

d. Desain bersifat sementara. Peneliti kualitatif menyusun desain secara terus-menerus disesuaikan dengan kenyataan di lapangan, desain tidak disusun secara kaku dan ketat seperti halnya penelitian kuantitatif tetapi disusun sesuai temuan-temuan penelitian di lapangan. Berdasarkan pernyataan tersebut penulis kemudian melakukan pengamatan penerapan Manajemen Boarding School dalam upaya meningkatkan kualitas belajar di SMP Nurul Hayah.

Dalam penelitian ini, peneliti bertindak sebagai instrumen sekaligus sebagai pengumpul data. Prosedur yang di pakai dalam pengumpulan data yaitu :

1. Observasi

Observasi adalah teknik pengumpulan data yang dilakukan melalui pengamatan, dengan disertai pencatatan-pencatatan terhadap keadaan atau perilaku obyek sasaran. (Abdurrahman: 2006: 104-105) Dalam hlm ini peneliti melakukan pengamatan langsung berkaitan dengan industri rumah tangga pada makanan kemasan industri rumah tangga, observasi tersebut di lakukan di Kelurahan Jepun Kecamatan Tulungagung Kabupaten Tulungagung pada Perusahaan Bawang Berlian dan Toko Sumber Rejeki. Dari hlm tersebut, peneliti mengkaji tentang persepsi masyarakat perlindungan konsumen pada makanan kemasan industri rumah tangga dan hukum perlindungan konsumen menurut Undang-Undang No.8 Tahun 1999.

2. Wawancara
Wawancara merupakan metode pengumpulan data dengan cara bertanya langsung (berkomunikasi langsung) dengan responden. Dalam berwawancara terdapat proses interaksi antara pewawancara dengan respoden.

Wawancara secara garis besar dibagi menjadi dua, yakni wawancara tak terstruktur dan wawancara terstruktur. Wawancara tak terstruktur sering juga disebut wawancara mendalam, wawancara intensif, wawancara kualitatif, dan wawancara terbuka (open ended interview), wawancara etnografis. Sedangkan wawancara terstruktur sering juga disebut wawancara baku (standardized interview) yang susunan pertanyaannya sudah ditetapkan sebelumnya (biasanya tertulis) dengan pilihanpilihan jawaban yang juga sudah disediakan. (Dedi Mulyanan: 2006: 120)

Dalam Proses wawancara, pasti akan ada kontak pribadi antara pewawancara dengan yang di wawancarai, maka dalam hlm ini, pewawancara dituntut untuk dapat mebaca situasi dan kondisi yang ada disana, seperti hlmnya memilih kapan dan dimana waktu yang baik untuk wawancara, Untuk mendapatkan hasil ataupun data yang valid, peneliti/ pewawancara. Hlm ini dilakukan agr wawancr dapat menghasilkan hasil atupun dat yng valid. (Sugiyono: 2006: 140)

Wawancara ditunjukan untuk menggali informasi seputar boarding school dari mulai sejarahnya sampai peran yang telah dilakukan boarding school sebagai sarana penunjang belajar siswa. Wawancara ini dilakukan peneliti di SMP Nurul Hayah Ketanggungan. Diharapkan peneliti akan mengetahui hlm-hlm yang lebih mendalam tentang partisipan dalam menginterprentasikan situasi dan fenomena yang terjadi, dimana hlm ini tidak bisa ditemukan melalui observasi.

3. Dokumentasi

Teknik dokumentasi yaitu mencari data mengenai hlm-hlm atau variabel yang berupa catatatn, transkip, buku, surat kabar, majalah, prasasti notulen rapat agenda, foto, dan lain sebagainya (Atik: 2012: 1). Dokumentasi dipergunakan untuk melengkapi sekaligus menambah keakuratan, kebenaran data atau informasi yang dikumpulkan dari bahan-bahan dokumentasi yang ada di lapangan serta dapat 
dijadikan bahan dalam pengecekan keabsahan data.

Analisis dokumentasi dilakukan untuk mengumpulkan data yang bersumber dari arsip dan dokumen yang berada ditempat penelitian atau yang berada diluar tempat penelitian yang ada hubungannya dengan penelitian tersebut. Metode ini digunakan untuk mengumpulkan data yang sudah tersedia dalam catatan dokumen. Fungsinya sebagai pendukung dan pelengkap bagi data-data yang diperoleh melalui observasi dan wawancara.

\section{HASIL DAN PEMBAHASAN}

Manajemen sangat diperlukan dalam sebuah organisasi yang berfungsi untuk mengatur proses penyelenggaraan organisasi hingga tercapainya tujuan (goal) dari organisasi tersebut. Contoh pada instansi pemerintah khususnya menyangkut soal pelayanan publik, diperlukan manajemen yang efektif dan efisien dalam proses penyelenggaraan pelayanan agar tercapainya tujuan dari pelayanan itu sendiri yakni kepuasan masyarakat.

Kata manajemen berasal dari bahasa Prancis kuno ménagement, yang memiliki arti seni melaksanakan dan mengatur. Selain itu juga, manajemen berasal dari bahasa inggris yaitu management berasal dari kata manage menurut kamus oxford yang artinya memimpin atau membuat keputusan di dalam suatu organisasi. Istilah manajemen yang diterjemahkan dari kata manage memang biasanya dikaitkan dengan suatu tindakan yang mengatur sekelompok orang di dalam organisasi atau lembaga tertentu demi mencapai tujuan-tujuan tertentu.

Peneliti mengutip definisi manajemen dari beberapa ahli. Manulang mendefinisikan manajemen sebagai suatu seni dan ilmu perencanaan, pengorganisasian, pengarahan, penyusunan dan pengawasan daripada sumber daya manusia untuk mencapai tujuan yang telah ditetapkan terlebih dahulu.(Malayu Hasibuan: 2009: 2)

G.R Terry mendefinisikan manajemen sebagai suatu proses yang khas yang terdiri dari tindakantindakan perencanaan, pengarahan dan pengendalian yang dilakukan untuk menentukan serta mencapai sasaran-sasaran yang telah ditentukan melalui pemanfaatan sumber daya manusia dan sumbersumber lainnya.
Sedangkan menurut Stoner dan Freeman manajemen adalah proses perencanaan, pengorganisasian, kepemimpinan, dan pengendalian upaya anggota organisasi dan proses penggunaan semua sumber daya organisasi untuk tercapainya tujuan organisasi yang telah ditetapkan.

Berdasarkan pengertian-pengertian manajemen yang telah dijelaskan diatas, maka dalam penelitian ini dapat dipahami bahwa manajemen merupakan suatu rangkaian kegiatan mulai dari perencanaan, pengorganisasian, pengarahan, pengendalian serta pengawasan dengan memanfaatkan sumber daya manusia serta sumber-sumber daya lainnya untuk mencapai suatu tujuan organisasi yang telah ditentukan.

\section{Fungsi-Fungsi Manajemen (Management Functions)}

Fungsi-fungsi manajemen adalah elemenelemen dasar yang selalu ada dan melekat di dalam proses manajemen yang akan dijadikan acuan oleh manajer dalam melaksanakan kegiatan untuk mencapai tujuan. Namun terdapat perbedaan pandangan mengenai fungsi-fungsi manajemen oleh beberapa ahli. George R. Terry mengungkapkan fungsi-fungsi manajemen meliputi Perencanaan (planning), Pengorganisasian (organizing), Pengarahan (actuating) dan Pengendalian (controlling).

Menurut Henry Fayol fungsi-fungsi manajemen meliputi Perencanaan (planning), Pengorganisasian (organizing), Pengarahan (commanding), Pengkoordinasian (coordinating), Pengendalian (controlling). Sedangkan menurut Ricki W. Griffin, fungsi-fungsi manajemen meliputi Perencanaan dan Pengambilan Keputusan (planning and decision making), pengorganisasian (organizing), Pengarahan (leading) serta pengendalian (controlling).

Dari perbandingan beberapa fungsi-fungsi manajemen di atas, dapat dipahami bahwa semua manajemen diawali dengan perencanaan (Planning) karena perencanaan yang akan menentukan tindakan apa yang harus dilakukan selanjutnya. Setelah perencanaan adalah pengorganisasian (organizing). Hampir semua ahli menempatkan pengorganisasian diposisi kedua setelah perencanaan. Pengorganisasian merupakan pembagian kerja dan 
sangat berkaitan erat dengan fungsi perencanaan karena pengorganisasian pun harus direncanakan.

Selanjutnya setelah menerapkan fungsi perencanaan dan pengorganisasian adalah menerapkan fungsi pengarahan yang diartikan dalam kata yang berbeda-beda seperti actuating, leading, dan commanding, tetapi mempunyai tujuan yang sama yaitu mengarahkan semua karyawan agar mau bekerjasama dan bekerja efektif untuk mencapai tujuan organisasi. Tetapi juga ada penambahan fungsi pengkoordinasian (coordinating) setelah fungsi pengarahan. Fungsi pengkoordinasian untuk mengatur karyawan agar dapat saling bekerjasama sehingga terhindar dari kekacauan, percekcokan dan kekosongan pekerjaan. Selanjutnya fungsi terakhir dalam proses manajemen adalah pengendalian (controlling). Pada fungsi manajemen ini, peneliti lebih cenderung memakai fungsi manajemen menurut Henry Fayol untuk menjawab penelitian mengenai manajemen pelayanan kebersihan.

Louis A. Allen perencanaan adalah menentukan serangkaian tindakan untuk mencapai hasil yang diinginkan. Sedangkan menurut ahli manajemen, Harold Koontz dan Cyril O’ Donnel perencanaan adalah fungsi daripada manajer di dalam pemilihan alternatif-alternatif, tujuan-tujuan kebijaksanaan, prosedurprosedur dan program. Koontz O' Donnell menjelaskan bahwa tipe-tipe perencanaan dapat dibedakan menjadi tujuan, kebijakan, prosedur, peraturan-peraturan, anggaran, program dan strategi. Sedangkan menurut Robert Anthony, perencanaan dibedakan menjadi tiga macam jenisnya, yaitu:

a. Perencanaan Strategis: Merupakan suatu proses perencanaan dimana keputusan tentang tujuan organisasi akan dicapai melalui pengelolaan sumber-sumber daya dan dana yang dimiliki, didasarkan pada kebijaksanaan yang telah ditetapkan sebelumnya.

b. Perencanaan untuk mengendalikan manajemen: Merupakan suatu proses perencanaan dimana manajer bertanggungjawab bahwa penggunaan sumber-sumber daya dan dana digunakan seefektif mungkin dan seefisien mungkin untuk mencapai tujuan organisasi.

c. Perencanaan operasional: Merupakan suatu proses dimana usaha melaksanakan kegiatan tertentu dijamin seefektif dan seefisien mungkin.

Dari beberapa definisi mengenai perencanaan, maka peneliti menyimpulkan bahwa perencanaan merupakan proses pemikiran dalam memilih dan menentukan program apa yang akan dilaksanakan di masa yang akan datang untuk mencapai hasil yang diinginkan.

\section{Implementasi Boarding School SMP Nurul Hayah}

1. Latar belakang diterapkannya program Boarding School di Sekolah

Sekolah dengan menerapkan program boarding school mulai bermunculan karena kemajuan zaman yang menuntut para orang tua untuk lebih memikirkan fondasi pendidikan agama dan pembentukan karakter yang kuat dalam diri anak sedini mungkin. Kemajuan teknologi yang sulit dihindari, sedikit banyak memberikan pengaruh negative terhadap anak- anak bahkan orang dewasa. Kecanggihan IT sangat merubah kebiasaan masyarakat, dari yang dahulunya sebuah keluarga hanya memiliki satu telefon rumah untuk kepentingan bersama, tetapi untuk saat ini fungsi telefon tergeser. Saat ini hampir setiap orang memiliki hand phone untuk kepentingan komunikasi, bahkan anakanak sekalipun. Keberadaaan hand phone pada anak-anak membuat mereka tidak lagi bisa membagi waktu untuk kegiatan rutin sehari-hari, dan juga merubah sikap anak-anak menjadi kurang tanggap dengan lingkungan, serta berpengaruh pula terhadap perkembangan akhlak. Di samping itu, tidak setiap orang tua dapat membimbing putra-putrinya dalam hal agama di rumah serta kesibukan dari sebagian orang tua yang pada akhirnya kurang waktu dalam memperhatikan belajar, sholat dan mengaji putraputrinya. Sehingga kualitas anak makin kesini makin menjadi menurun. Banyak siswa sudah kelas 7 tetapi masih sangat kurang dalam hal mengaji. Hal ini sangat memprihatinkan dan menjadi kendala 
pembelajaran di SMP Nurul Hayah.

$$
\text { Menurut bapak Sam'ani, }
$$

S.Pd.I. yang memprakarsai program boarding school di SMP Nurul Hayah, mengatakan bahwa (Wawancara Ust. Abdussalam) :

"Latar belakang dilaksanakannya program boarding school ini yang pertama, karena adanya keprihatinan sekolah yang nota bene banyak pelajaran agamanya akan tetapi untuk di daerah perkotaan anak-anak masih sangat kurang dalam hal membaca al-Quran yang baik, karena di rumah masing-masing tidak mengaji atau tidak ada masjid maupun mushola yang menyelenggarakan belajar mengaji. Sementara orang tua juga tidak punya waktu ataupun kemampuan untuk mengajarkan anak-anaknya mengaji di rumah. Kedua, Pembelajaran agama bukan hanya sekedar teori, tetapi pelajaran yang harus dipraktikkan. Di sekolah yang waktunya terbatas tidak dapat untuk memantau pengamalan pelajaran agama anak, karena keterbatasan waktu di sekolah belum dapat memperlihatkan keseharian anak secara menyeluruh dan pihak sekolahpun belum dapat memperlihatkan secara menyeluruh kehidupan beragama yang baik seperti apa, maka anak-anak perlu untuk diasramakan. Karena tujuan utama boarding school adalah internalisasi nilainilai keagamaan dalam diri siswa. Internalisasi itu mulai dari siswa melihat, mendengarkan, memperhatikan, kemudian mencoba melakukan dan mempraktikkan semua teori agama yang telah dipelajari. Dan dalam boarding school, kegiatan-kegiatan keagamaan yang wajib maupun yang sunah dikonteskan seperti lomba Pidato dan lomba hafalan Al-Quran, dll. Lombalomba yang lain di antaranya keterampilan berbicara bahasa Arab dan Inggris, berpidato, sholawat, lomba kreasi antar kamar, lomba senam kreasi, lomba gerak tari Islami, lomba Drama, Bazar, lomba cipta lagu, dll. Karena waktu dalam asrama cukup longgar, maka ada waktu untuk bimbingan belajar mata pelajaran sains. Banyaknya mata pelajaran yang dipelajari di sekolah membuat porsi mata pelajaran sains berkurang, sehingga perlu untuk menambah belajar di luar jam sekolah. Hal ini hanya bisa dilaksanakan bila siswa diasramakan. Sehingga secara simultan baik pengetahuan tentang agama, pengamalan sikap, dan bagaimana penguasaan terhadap sains dan teknologi dapat diraih, juga kemudian dikembangkan dengan seni, keterampilan dan olahraga yang dilaksanakan dalam hari-hari tertentu."

Pemikiran ini tentu tidak bisa langsung direalisasikan begitu saja, tetapi butuh dipikirkan bersama oleh kepala sekolah, guru, orang tua dan lingkungan sekolah. Karena mewujudkan sebuah boarding school membutuhkan banyak persiapan. Terutama asrama yang tidak mungkin bisa dibangun dalam waktu yang singkat dan membutuhkan banyak biaya. Tentu sangat membutuhkan pemikiran dan sumbangan dana dari berbagai pihak. Yang tidak kalah pentingnya, merencanakan kegiatan-kegiatan keagamaan, kegiatan-kegiatan yang mendukung pembelajaran di sekolah, dan kegiatankegiatan lainnya yang harus dicukupi untuk pengembangan bakat siswa, serta para guru yang mendampingi siswa setiap harinya dalam asrama. Dan tidak ketinggalan pula kesiapan mental siswa yang tadinya sangat nyaman di rumah bersama orang tua, dan dengan segala fasilitas yang dapat tercukupi dengan mudahnya, lalu tinggal di asrama jauh dari orang tua dan keluarga serta dengan fasilitas yang terbatas, karena dalam asrama banyak teman tidak seperti di rumah.

Pendidikan Pesantren yang kental dengan nilai-nilai agama terbukti sangat membantu orang tua dalam membentengi putra-putrinya dari perbuatan-perbuatan yang tidak baik dan akhlak-akhlak tercela yang tidak sesuai dengan norma dan agama serta dapat membentengi dari pengaruh kemajuan teknologi informasi yang sangat pesat, dan tidak semua informasinya baik untuk diakses dan ditiru oleh semua lapisan masyarakat, perkembangannya yang tidak mengenal batas ruang, waktu, serta usia, dan sangat mudah dijangkau oleh masyarakat, tua maupun muda. Dan juga dapat membentengi putraputrinya dari pengaruh lingkungan yang tidak selalu baik sesuai harapan semua orang, kenakalan-kenakalan remaja mulai dari 
minum-minuman keras, narkotika dan obatobat terlarang, permainan judi, sabung ayam, pergaulan bebas, dan lain-lain.

Boarding school hadir dengan model pendidikan yang mengisolasi siswa dari pengaruh lingkungan masyarakat yang negative merupakan salah satu alternative dalam mengatasi berbagai masalah tersebut. Siswa dapat hidup dengan tenang dan khusyuk dalam menjalankan kegiatankegiatan yang sangat positif. Di boarding school para siswa dapat belajar lebih maksimal, focus, dan berinteraksi langsung dengan guru, terkontrol segala aktivitasnya serta lebih dapat mengembangkan kemampuan diri dalam keterampilan/skill yang dimiliki. Siswa lebih mandiri dan tumbuh rasa percaya diri akan kemampuannya karena terbiasa dan terlatih dalam kontes- kontes yang diselenggarakan di boarding school.

Seperti dalam pesantren, dalam boarding school pun dijaga dengan ketat agar siswa tidak terkontaminasi oleh hal-hal yang tidak sesuai dengan sistem pendidikan atau ciri khas suatu sekolah berasrama. Dengan demikian siswa terlindungi dari hal-hal yang negative seperti merokok, narkotika dan obata-obatan terlarang, tayangan film/sinetron yang tidak mendukung pendidikan dan sebagainya. Selain itu melalui pergaulan yang baik dengan para guru atau musyrif-musyrifah, siswa akan mendapatkan uswah atau contoh yang baik dan praktik dari nilai-nilai moral atau akhlakul karimah secara langsung dalam kehidupan sehari-hari, seperti tertib beribadah, disiplin waktu, belajar mandiri dan hormat serta patuh terhadap perintah guru dan para musyrifmusyrifahnya, serta hidup bersosialisasi dengan teman-teman sekamar. Hal ini akan menjadi fondasi yang kuat dalam diri siswa dan menjadi bekal hidup sepanjang masa. Dengan demikian, pendidikan kognitif, afektif, dan psikomotor siswa dapat terlatih dengan lebih baik dan optimal.

Meskipun dalam papan nama SMP Nurul Hayah tidak terpampang kata boarding school, namun awal didirikannya, SMP Nurul Hayah telah menerapkan program boarding school yang semakin tahun menunjukkan perkembangannya dengan baik boarding school di SMP Nurul Hayah ini harus tetap dipertahankan untuk pendidikan karakter siswa. Karena pembiasaan itu dapat diterapkan dan dinilai terus menerus ketika siswa berada dalam boarding school. Dari pagi hari bangun tidur sampai menjelang tidur lagi semua perilaku siswa dapat dipantau oleh guru. Dari mandi, wudhu, sholat jamaah, baca al- Quran, kedisiplinan, kebersihan, sosialisasi dengan teman, semuanya dapat dipantau bila ada boarding school. Apa yang diajarkan dan yang dikehendaki oleh sekolah dapat dilaksanakan dan dinilai ketika ada boarding school. Ketika siswa sudah pulang ke rumah, guru tidak bisa memantau dan tidak bisa menilai kebiasaan siswa dan proses belajarnya seperti apa. Ketika dalam boarding school, cara makan siswa bisa dilatih untuk tertib dalam mengantri, berdoa sebelum dan sesudah makan, mencuci piring sendiri, lalu menata tempat tidur, menata baju, dan lain sebagainya. Sehingga manfaat yang luar biasa dapat dirasakan oleh semua pihak yaitu yang pertama menjadi anak yang mandiri, yang kedua mempersiapkan mental siswa yang akan melanjutkan ke pondok pesantren setelah lulus dari SMP Nurul Hayah. Siswa yang melanjutkan ke pondok pesantren manapun tidak akan menemukan masalah karena sudah terbiasa dan terlatih hidup nyantri dan mandiri dalam boarding school. Orang tua juga merasa senang dan tenang karena anaknya bisa langsung adaptasi. Bedanya ketika dalam boarding school adalah bersama dengan teman- teman yang sudah dikenal sejak kelas 7, sedangkan ketika di pondok pesantren, bersama dengan temanteman yang baru dikenal. Ketiga yaitu nilai ujian sekolah maupun ujian nasional, karena dalam boarding school ada bimbingan belajar atau bimbel setelah sholat Subuh dan setelah sholat Ashar, yang mata pelajarannya sudah terjadwal dengan baik, sehingga nilainya menjadi lebih baik.

Sebagaimana sekolah-sekolah lain pada umumnya, SMP Nurul Hayah juga memiliki ciri khas tersendiri yaitu dengan 
program boarding school sekalipun baru merupakan sekolah di tingkat dasar dan di bawah naungan pemerintah, tetapi SMP Nurul Hayah dengan penuh keyakinan akan dapat menjadi sebuah sekolah pilihan masyarakat yang membutuhkan dan menjadi kebanggaan masyarakat.

\section{KESIMPULAN}

Berdasarkan data dan hasil penelitian di lapangan tentang Manajemen Boarding School di SMP Nurul Hayah, maka dapat diambil kesimpulan bahwa:

1. Pola manajemen boarding school di SMP Nurul Hayah adalah pola manajemen terintegrasi antara boarding school dengan Sekolah. Manajemen asrama memiliki tujuan internalisasi nilai-nilai keagamaan dalam diri siswa sedini mungkin, pendidikan akhlakul karimah, memiliki khasanah keilmuan Islam serta menumbuhkan bakat, potensi, dan skill sebagai bekal hidup siswa di masa yang akan datang. Dan manajemen sekolah memiliki tujuan membentuk peserta didik yang cerdas, kreatif, berakhlaqul karimah, dan tangguh. Visi misi tersebut tidak dapat diwujudkan tanpa adanya integrasi antara boarding school dan sekolah. Melalui integrasi antara manajemen boarding school dengan sekolah dalam segala bidang dapat tercapai generasi muda insan kamil yang kelak akan menjadi pemimpin masyarakat yang mampu menjawab tantangan zaman.

2. Manajemen Boarding School di SMP Nurul Hayah secara rinci adalah sebagai berikut:

a. Perencanaan Boarding School.

Kegiatan perencanaan Boarding School dengan langkah-langkah sebagai berikut: (1) menetapkan tujuan dan target Boarding School, (2) merumuskan strategi untuk mencapai tujuan dan target Boarding School, (3) menentukan sumber daya yang diperlukan, (4) menetapkan standar atau indikator keberhasilan pencapaian tujuan dan target Boarding School

b. Pengorganisasian Boarding School.

Fungsi pengorganisasian dalam boarding school meliputi: (1) mengalokasikan sumber daya, merumuskan dan menetapkan tugas, dan menetapkan prosedur yang diperlukan dalam program boarding school, (2) menetapkan struktur organisasi yang menunjukkan adanya garis kewenangan dan tanggungjawab, (3) kegiatan perekrutan, penyeleksian, pelatihan dan pengembangan sumber daya manusia/tenaga kerja, (4) kegiatan penempatan sumber daya manusia pada posisi yang paling tepat.

c. Penggerakan dan pelaksanaan Boarding School.

Dalam pelaksanaan kegiatan boarding school di SMP Nurul Hayah sudah dapat berjalan dengan lancar dan maksimal, masing- masing lembaga telah telah melaksanakan peran dan tugasnya dengan baik, para guru, asatidz melaksanakan kegiatan pembelajaran dengan bervariasi, sehingga membuat siswa-siswa Sedangkan musyrif/ musyrifah ikut aktif dalam upaya meningkatkan kualitas belajar di dalam asrama sehingga anak akan menjadi aktif dan bersemangat dalam kegiatan Pembelajaran. Sekalipun terkadang masih ada beberapa siswa yang rindu dengan keluarga ataupun merasa capek dengan padatnya aktivitas dalam setiap hari.

d. Pengawasan dan Evaluasi Boarding school.

Pengawasan yang dilaksanakan dalam boarding school SMP Nurul Hayah ini dilaksanakan oleh Kepala Sekolah sendiri, adapun bentuk pengawasan yang dilakukan di SMP Nurul Hayah antara lain: (1) Pengawasan secara langsung, (2) Pengawasan secara lisan, dan terakhir (3) Pengawasan dalam bentuk tulisan /laporan.

Adapun evaluasi program boarding school dalam bidang akademik meliputi ketercapaian target-target bimbel mata pelajaran sains, penguasan bahasa serta hafalan Al Qur'an. Sedangkan evaluasi kegiatan non akademik dilaksanakan secara berkala pada rapat pengurus boarding school yang dilaksanakan sebulan sekali dalam rapat bulanan dan pada akhir semester Dilihat dari empat 
kegiataan manajemen boarding school yang terjadi telah dilaksanakan di SMP Nurul Hayah, dapat diketahui bahwa proses pembelajaran telah melibatkan interaksi tidak hanya saat KBM formal di pagi hari saja, tetapi proses pembelajaran belangsung selama sehari full, dari pagi sampai malam hari, mereka dikondisikan dan teroganisir dalam upaya menggapai tujuan pendidikan. Hal ini selaras dengan apa yang dikatakan para ahli tentang pembelajaran yang berkualitas, maka dapat disimpulakan bahwa pembelajaran di SMP Nurul hayah telah melakukan upaya-upaya dalam meningkatkan kualitas pembelajaran.

3. Kendala dan solusinya dalam pelaksanaan Manajemen Boarding School dalam upaya meningkatkan kualitas pembelajaran

a. Kendala - kendala

1) Terbatasnya guru - guru yang mempunyai latar belakang pondok pesantren, atau pendidikan berasrama.

2) Kurikulum yang masih berubahubah setiap tahunnya.

3) Fasilitas yang belum sepenuhnya terpenuhi dan tidak berfungsinya beberapa fasilitas di sekolah maupun pondok

4) Jarak yang cukup jauh dari asrama menuju masjid dan ruang kelas.

b. Solusi

Adapun solusi dari kendala-kendala diatas anata lain:

1) Adanya bimbingan pendidikan kepesantrenan dari pihak pondok untuk guru yang sudah mengajar dan rencana perekrutan guru baru yng mempunyai latar belakang pesantren, karena kedepannya seluruh guru di haruskan untuk tinggal dipondok sekaligus mengawasi para siswa.

2) Adanya evaluasi di akhir tahun dan perencanaan perangkat pendidikan yang matang agar kurikulum bersifat paten dan tidak berubahubah

3) Untuk fasilitas yang belum terpenuhi, maka solusinya yaitu akan adanya rencana penambahan ruang kelas dan asrama baru untuk siswa di tahun mendatang, dan untuk fasilitas yang tidak berjalan seperti air mampet, Ac yang tidak berfungsi, pihak pondok harus selalu berkordinasi secara intens dengan pa Imam, ketua tukang dan penaggung jawab semua fasilitas di asrama dan sekolah di setiap waktu.

4) Jarak yang cukup jauh mengakibatkan para siswa terkadang malas-malasan dan ini berakibat pada proses pembelajaran yang molor dari waktu sebenarnya, maka dalam hal ini, pihak pondok berkordinasi dengan pihak keamanan, dari Pembina keamanan, ospen keamanan bahkan dengan Musyrif dan Musyrifah.

\section{DAFTAR PUSTAKA}

Abdurrahman, Fatoni. 2006. Metodologi Penelitian dan Tehnik Penyusunan Skripsi, Jakarta: PT. Rinekha Cipta 2006

Al Barry, M. Dahlan. 2001. Kamus Modern Bahasa Indonesia Yogyakarta : Arloka.

Al-Khalili, Amal Abdussalam. 2005. Mengembangkan Kreativitas Anak, Jakarta: Pustaka Al-Kautsar. 
Arikunto, Suharsimi. 2006. Prosedur Penelitian Suatu Pendekatan Praktek, Edisi Revisi, jakarta: Renika Cipta.

Asmani, Jamal Ma'mur. 2009. Full Day School: Konsep, Manajemen, Quality Control Yogyakarta: Ar-Ruz Media.

Atik \& Ratminto. 2012. Manajemen Pelayanan Yogyakarta: Pustaka Pelajar,

A Supriyanto, Jurnal Ilmu Pendidikan Sekolah Dasar di Daerah Diseminasi November 1997, Jilid 4 IKIP : 1997

Bukhram. 2017. Sistem Boarding School Dalam Upaya Meningkatkan Kualitas Pembelajaran di SMP Islam Jabal Hikmah.

Choliq, Abdul. 2011. Pengantar Manajemen, Semarang: Rafi Sarana Perkasa,cetakan pertama Desember.

Departemen Agama RI. 2003. Pola pembelajaran di Pesantren Jakarta.

Hamalik, Oemar. 2008. Perencanaan Pembelajaran Berdasarkan Pendekatan Sistem, Bandung: Bumi Aksara.

Handoko, T. Hani. 2001. Manajemen Personalia dan Sumber Daya Manusia Yogyakarta: BPFE Yogyakarta.

Hasanah, Aan. 2012. Pengembangan Profesi Keguruan Bandung: Pustaka Setia

Hasibuan, Malayu. 2009. Manajemen: Dasar, Pengertian dan Masalah Jakarta: Bumi Aksara.

Hendriyenti, Pelaksanaan Program Boarding Schooldalam Pembinaan Moral Siswa di SMA Taruna Indonesia Palembang

John M. Echols \& Hassan Shadily. 2010 . Kamus Inggris Indonesia: An EnglishIndonesian Dictionary (Jakarta: Gramedia.

Komalasari, Kokoh 2010. Pembelajaran Kontekstual Konsep dan Aplikasi, Bandung: Refika Aditama. 